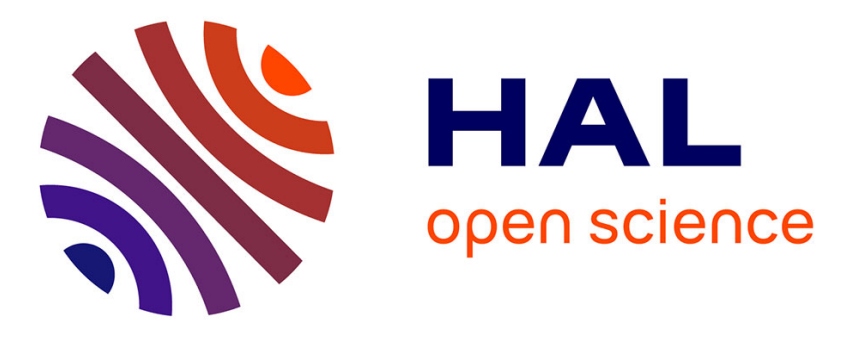

\title{
Fertilization and fertility in the female of Varroa destructor, a key point for the parasite population dynamics
}

Sébastien Wendling, Bertrand Guillet, Lise Roy, Serge Kreiter, Marc-Edouard Colin

\section{To cite this version:}

Sébastien Wendling, Bertrand Guillet, Lise Roy, Serge Kreiter, Marc-Edouard Colin. Fertilization and fertility in the female of Varroa destructor, a key point for the parasite population dynamics. Apidologie, 2014, 45 (6), pp.722-732. 10.1007/s13592-014-0291-4 . hal-01234774

\section{HAL Id: hal-01234774 https://hal.science/hal-01234774}

Submitted on 27 Nov 2015

HAL is a multi-disciplinary open access archive for the deposit and dissemination of scientific research documents, whether they are published or not. The documents may come from teaching and research institutions in France or abroad, or from public or private research centers.
L'archive ouverte pluridisciplinaire HAL, est destinée au dépôt et à la diffusion de documents scientifiques de niveau recherche, publiés ou non, émanant des établissements d'enseignement et de recherche français ou étrangers, des laboratoires publics ou privés.

$$
\text { Copyright }
$$




\title{
Fertilization and fertility in the female of Varroa destructor, a key point for the parasite population dynamics
}

\author{
Sébastien Wendling ${ }^{1}$, Bertrand Guillet ${ }^{1}$, Lise Roy ${ }^{2}$, Serge Kreiter ${ }^{3}$, \\ Marc-Edouard CoLIN ${ }^{1}$ \\ ${ }^{1}$ Montpellier SupAgro, USAE, Domaine de Lavalette, 900 rue J.-F. Breton, 34090 Montpellier, France \\ ${ }^{2}$ Centre d'Ecologie Fonctionnelle et Evolutive, UMR 5175, Ecologie des Arthropodes, Université Paul Valéry \\ Montpellier III, Route de Mende, 34199 Montpellier, France \\ ${ }^{3}$ Montpellier SupAgro, UMR CBGP, Campus International de Baillarguet, CS 30016, 34988 Montferrier, France
}

Received 3 October 2013 - Revised 10 April 2014 - Accepted 29 April 2014

\begin{abstract}
In Varroa destructor, the spermathecal content allows the female mite to carry out several successive reproductive cycles after a single mating event. The present study aimed to identify the main factors influencing the sperm content. Mite adult females were sampled at different bee colony phenological phases and on different host stages/sexes. Spermatozoa was characterized and counted. Spermatozoa maturity was acquired sufficiently fast (less than 5 days after the imaginal moult), their viability (ca. 91.5\%) and the fertilization success (ca. 1 spermatozoa spent per oocyte) were sufficiently high so that none of these parameters were limiting factors in the dynamics of mite populations. Moreover, no modulation was detected in the spermathecal content according to the brood status and the seasonal activity of the colony.
\end{abstract}

Varroa destructor / Apis mellifera / parasite / spermatheca / reproductive success

\section{INTRODUCTION}

In many parasitic or parasitoid arthropods, the dual necessity of an encounter between the male and the female, for fertilization purposes, and between the female and the host, for maturation or egg-laying, requires a time lag between mating and egg-laying. The strategies used to make it possible are varied: time lag between fertilization and egg-laying by the retention of fertilized eggs in the case of the female chicken red mite Dermanyssus gallinae

Corresponding author: S. Kreiter, kreiter@supagro.inra.fr Manuscript editor: Yves Le Conte
Dugès (Oliver 1966, 1977; Hutcheson and Oliver 1988), time lag between mating and fertilization by the conservation of sperms in endospermatophores provided by male soft ticks (Argasidae: Vial 2009) and hard ticks (Ixodidae: e.g., Kiszewsky and Spielman 2002), or in the female organs, such as in the spermatheca of Varroa destructor Anderson and Trueman (Acari: Mesostigmata, Varroidae). Spermathecae are very common organs in arthropods, which allow the conservation of live sperms for several months and for years in some cases, e.g., in queens of social insects (more than 8 years in Apis mellifera L.: Winston 1993; Al-Lawati et al. 2009).

$V$. destructor is a hematophagous ectoparasite which rages on $A$. mellifera in the form of epizooties since its recent adaptation to this new 
host (Anderson and Trueman 2000). Most colonies do die in approximately 3 years of varroosis if no therapeutic measure is taken. The mite cycle is precisely synchronized with the development of its host (Frey et al. 2013).

The pathogenic actions of the mite on its host are as follows: it damages the cuticles, sucks the hemolymph, can transmit or activate bee viruses at every one of its host development stage, and takes advantage of bees' movements to transit from one individual to another, indeed from one colony to another (Rosenkranz et al. 2010).

A reproduction cycle has two phases: a phoretic phase, which is of variable duration depending on the brood availability (Akimov et al. 1988; Beetsma et al. 1999), as well as a reproduction phase of which the duration depends on the reproduction specificities of its host. The reproduction phase begins just before cell capping (the bees' L5 stage) and continues until the bee emerges ( $280 \mathrm{~h}$ for the worker bee and $360 \mathrm{~h}$ for the drone; see (Donzé and Guérin 1994; Martin 1994, 1995)). On average, a female $V$. destructor goes through several reproduction cycles in its life span, in natural conditions: 1.5 to 2 cycles (Fries and Rosenkranz 1996) or 2 to 3 cycles (Martin and Kemp 1997). The eggs are laid solely by fertilized foundress females inside the sealed cells of the workers' brood (five eggs, rarely six), and of drones (six eggs, rarely seven), at a rate of one egg every $30 \mathrm{~h}$. The first egg laid 60 to $70 \mathrm{~h}$ after cell capping is a male (a haploid male from a unfertilized egg, through arrhenotokous parthenogenesis), followed by females (diploid from fertilized eggs) (for review see Rosenkranz et al. 2010). At most, a foundress female lays approximately 30 eggs in its life, according to Akimov and Yastrebtsov (1984).

During its life span, the female $V$. destructor has only one fertilization period just after the imaginal moult. Matings occurring with the mother are all unsuccessful (Donzé et al. 1996). In cases of mono-infestation, mating between the male and its sisters occurs in successive episodes with the male changing partners as soon as one more female has moulted, that is approximately $30 \mathrm{~h}$ after the preceding female has moulted. During the mating process, the male deposits a spermato- phore containing immature spermatozoa (abbreviated as "spz"), ovoid in shape (40 $\mu \mathrm{m}$ in diameter) through the spermatodactyl pair of its two chelicerae at the level of the female's solenostomes. Following a transfer into the female reproductive system, lasting several hours, the spz arrives into the spermatheca and takes the shape of ribbons, 180 to $230 \mu \mathrm{m}$ long (Donzé et al. 1996). The reproductive potential of a female is likely to mainly depend on the number of spz contained in the spermathecae and the number of oocytes to be fertilized.

Some cases of infertility can be of intrinsic origin, related to the absence or exhaustion of gametes (spz or oocytes) (Akimov et al. 1988; Fuchs 1994; Harris and Harbo 1999), or due to their immaturity (Fries and Rosenkranz 1996). However, the hypothesis, according to which infertility may be associated with the host's resistance, has also been argued in the case of $V$. destructor (Rosenkranz et al. 2009; Kirrane et al. 2011).

The aim of our research is to bring forth information on the factors influencing spz content on adult $V$. destructor female spermathecae, as being an important part of the reproductive success of the parasite. More particularly, and in order to estimate the influence of the host colony phenology on the spermathecal content, samples were taken when colonies had a little or no brood and when colonies had large amounts of brood. To find out if phoretic females, with no or little spz reserve, nevertheless parasite the brood, samples from parasites were taken on adult bees and in capped brood cells. To determine whether there is a connection between a sperm reserve and the fertilization of oocytes, samples between foundress females and nulliparous adult daughters were compared.

\section{MATERIAL AND METHODS}

\subsection{Biological material: Adult V. destructor females}

A pool of five colonies from Montpellier SupAgro experimental apiary, not treated against $V$. destructor 
since 3 years, was used to ensure a sufficient number of parasites. Different samples were taken:

- sets of phoretic female adults taken from adult bees on four episodes during the year: October, December, March, and July with a minimum of 30 successful dissections of mites for each period,

- sets of adult females collected inside the drone brood sealed cells. For each opened cell infested by parasites, the developmental stages of drones were determined according to morphological criteria used by Martin (1995). Data on the number of adult females present in the cell, their color as well as the morphology of spz in the spermathecae (Akimov et al. 1988) were collected. These criteria are essential to enable the distinction between foundress females and daughter females.

- sets of adult females collected from the broods of workers and drones especially to test viability (the ratio of live spz on the total number of spz). Data were collected in various ways during a study period of 2 months. Female mites were classified according to brood gender and according to the color of their cuticle (light or dark). Viability was estimated from spermathecae containing more than $10 \mathrm{spz}$.

\subsection{Dissection protocol}

$V$. destructor collected adult females were anesthetised in low temperatures $\left(-22^{\circ} \mathrm{C}\right)$ for a duration of $5 \mathrm{~min}$, glued from their dorsal side, then immersed in a PBS solution. Dissection was carried out by means of a stereomicroscope with $\times 50$ magnification.

In order to have access to the internal organs, the genito-ventral scutum, the two posterior metapodal scuta and the anal scutum were removed through dissection. The reproductive organs are visible after removing the lobes of the gastric caeca, the rectum and the Malpighian tubules, as described by Harris and Harbo (1999). The spermatheca and the lyriform organs appear in the form of three transparent bags. These reproductive organs are then retrieved with thin pliers and placed between a slide and a coverslip in a glycerol and eosin solution in equal proportions
(Björndahl et al. 2003) (Figure 1a, b). From this coloration, with magnification levels of $\times 100$ and $\times 400$, it is possible to count directly the spz by means of optical microscopy and to distinguish the maturing stage of spz and whether they are dead or alive by means of phase contrast microscopy (Figure 1c).

Moreover, a spermatheca is a very fragile organ, and spz may be lost during the critical manipulation stage. In this case, the presence of spz is only noticed without quantification.

\subsection{Statistical analyses}

On the basis of the results obtained from counting the number of spz of different categories of mites, the significance of observed differences was measured by means of parametric tests (Gaussian distribution) or non-parametric tests, with SigmaStat for Windows Version 2.03. Software package. Thus, (i) the Anova test was used for the analysis of the spermathecal content of phoretic females according to certain periods of the year, (ii) the Wilcoxon-MannWhitney test for comparing spz counts between phoretic and foundress females having laid at least one egg, (iii) the student $t$ test for comparing the global number of spz between foundress females having completed the egg-laying process and nulliparous adult daughters, (iv) the $\chi^{2}$ test for comparing observed frequencies of empty spermathecae between daughter-females and phoretic and foundress females.

\section{RESULTS}

\subsection{Counting and maturing stage of $\operatorname{spz}$ contained in the spermathecae of phoretic females on four periods during the year}

There was no significant difference with regard to spz content during the four periods under study $(F=0.538, \quad \mathrm{df}=3, \quad P=0.657)$ (Figure 2). The mean spermathecal content was $31.0 \mathrm{spz}$ in October $(n=32), 31.7 \mathrm{spz}$ in December $(n=30), 35.0 \mathrm{spz}$ in March $(n=30)$, and $32.3 \mathrm{spz}$ in July $(n=28)$. In July, $7.2 \%$ of females revealed $\mathrm{spz}$ of the immature type, which indicated that they were daughters. 

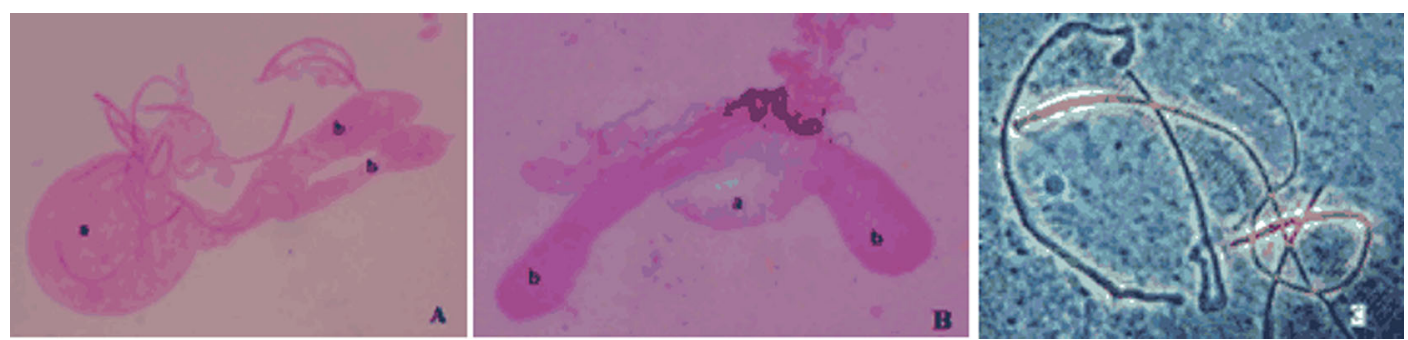

Figure 1. Reproductive organs of Varroa destructor adult females after dissection: A spermatheca with spermatozoa $(a)$ and lyrate organ $(b), \mathbf{B}$ an empty spermatheca $(a)$ and lyrate organ $(b)$, $\mathbf{C}$ spermatozoa of Varroa destructor after coloration: the colorant has totally penetrated in dead ones whereas it remains outside the living ones (bright yellow).

\subsection{Spz count in phoretic and foundation females having laid at least one egg}

The mean spermathecal content was $32.3 \mathrm{spz}$ for all phoretic dissected females $(n=120) ; 36.9 \mathrm{spz}$ for foundress females $(\mathrm{U}=3875 ; P=0.364)$ (Figure 3).

\subsection{Total comparison of the number of $\mathrm{spz}$ in foundress females having completed their egg-laying process and in nulliparous adult daughters}

The mean spermathecal content was 44.3 for adult female daughters $(n=42)$, it was $34.4 \mathrm{spz}$ for foundress females $(n=30)$. This difference was significant $(t=2.229 ; P=0.029)$ (Figure 4).

\subsection{Spz viability}

There was no significant difference between the four sample categories $(\mathrm{H}=7.163, \mathrm{df}=3, P=$ 0.067). The percentage of live spz, in foundation females or daughters, collected from the drone brood, was strikingly high: $91.5 \pm 2.5 \%$ $(n=58)$ (Figure 5).

\subsection{Infertility and frequency of empty spermathecae}

Two phoretic females out of the 30 dissected in July had an empty spermatheca, being $6.7 \%$ of phoretic females. Out of the 49 foundation females observed in the brood following the

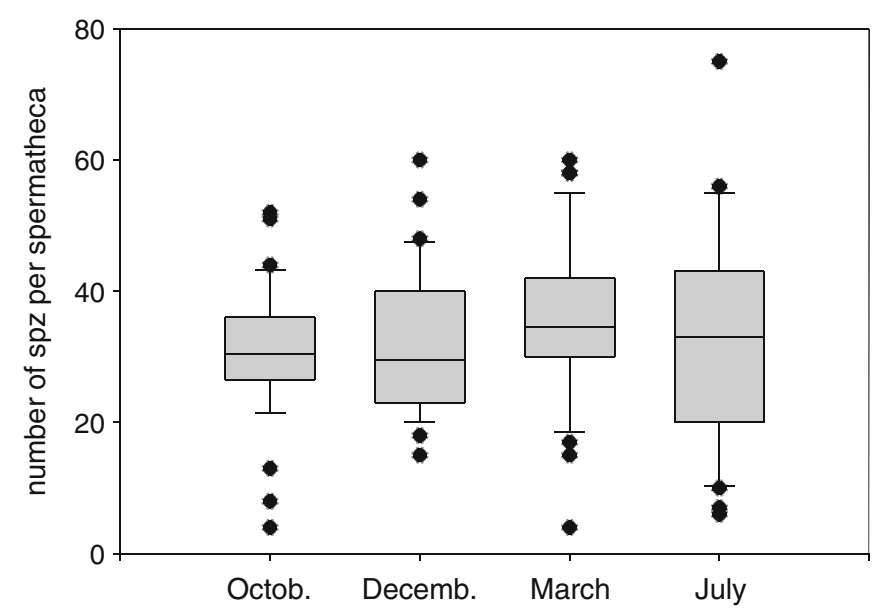

Figure 2. Box plots of spermatozoa counts per spermatheca of phoretic females of Varroa destructor: October $n=32$ spermathecae, December $n=30$, March $n=35$, July $n=28$. 


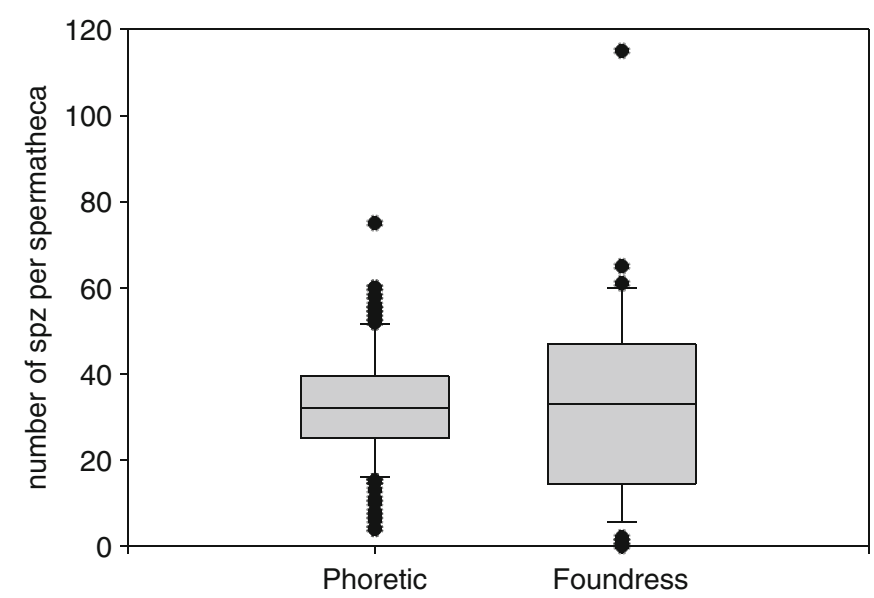

Figure 3. Box plots of spermatozoa counts per spermatheca of phoretic females $(n=120)$ and by foundress females $(n=44)$ of Varroa destructor.

egg-laying period, seven presented no offspring (14.3\%). We counted 41, 8, 16, 24, and $22 \mathrm{spz}$ in five of them, and only two had an empty spermatheca $(4.1 \%)$. As for daughter-females, 14 out of 64 revealed empty spermathecae $(21.9 \%)$. The difference in the observed frequencies of empty spermathecae was significant $\left(\kappa^{2}=9.195, \mathrm{df}=2, P=0.01\right)$ between daughter-females and all phoretic and foundress females. The absence of spz was associated with an absence of males in the cell for 11 of these daughter-females.

\section{DISCUSSION}

The results reflect the local situation of one experimental untreated apiary of Montpellier in the Mediterranean area of France.

\subsection{Mean and maximum spermathecal contents}

The mean spermathecal content in $V$. destructor females is between 31 and $45 \mathrm{spz}$ for all the different populations of mites under

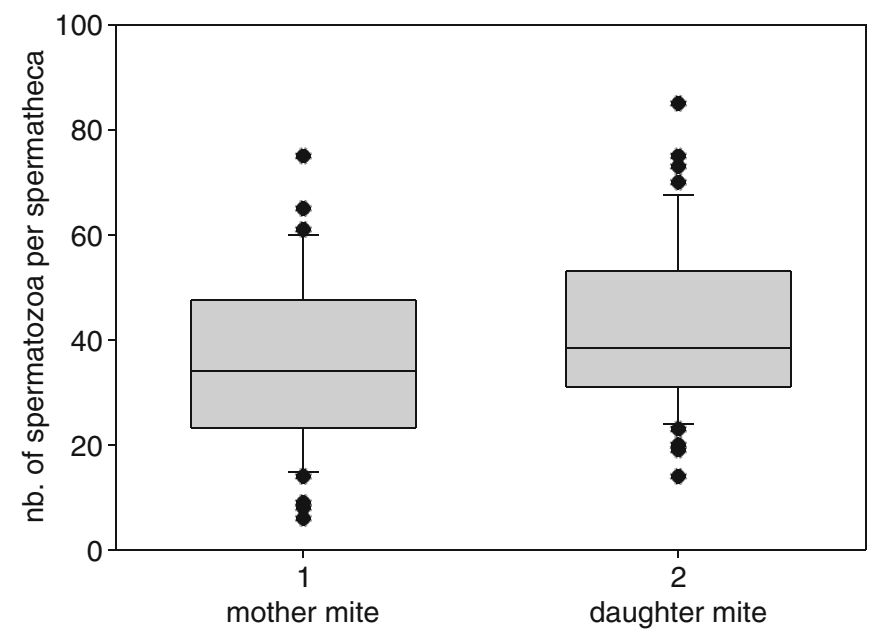

Figure 4. Box plots of spermatozoa counts per spermatheca of foundress females $(n=30)$ and of daughterfemales $(n=42)$ of Varroa destructor. 


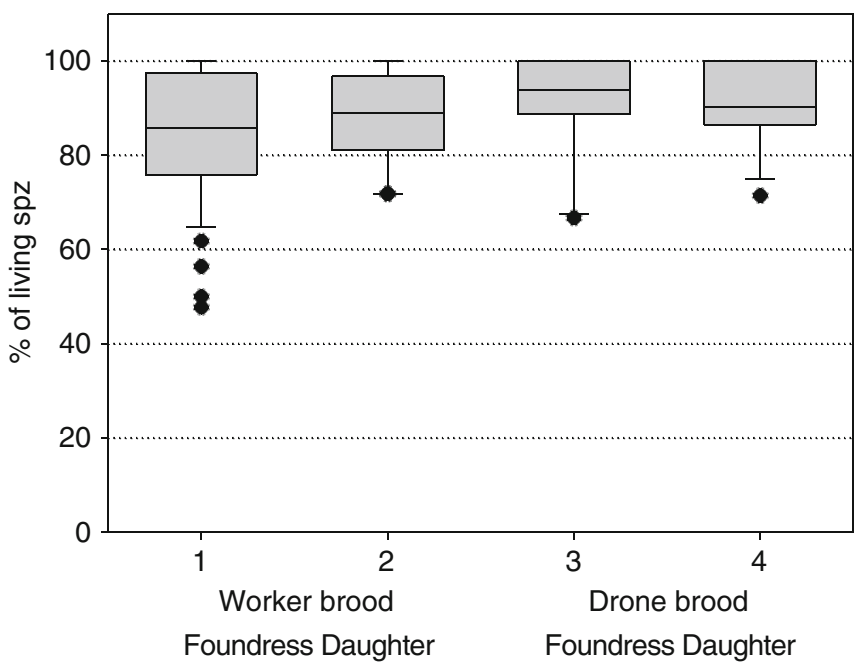

Figure 5. Box plots of spermatozoa viability per spermatheca of foundress females taken out worker brood $(n=$ $45)$, of daughter-females out worker brood $(n=17)$, of foundress females out drone brood $(n=45)$, of daughterfemales out drone brood $(n=13)$ of Varroa destructor.

study. It is difficult to draw a comparison with other studies carried out on these species, on account of their small sampling size. As an indication, Harris and Harbo (1999) yielded such averages as $22 \mathrm{spz}(n=27)$ and $35 \mathrm{spz}(n=$ 18) for foundress females producing an offspring. The maximum spermathecal content observed in our study is $115 \mathrm{spz}$. It was 75 spz for Donzé et al. (1996).

The spermathecal count appears rather low in the case of the $V$. destructor if one compares it to most free insects for which this type of data is available. Such a low number of spz is found in some parasitoid Hymenoptera (128 spz on average in Eupelmus orientalis Crawford (Eupelmidae) and $79 \mathrm{spz}$ in Dinarmus basalis Rond (Pteromalidae), Damiens et al. 2002). It is, however, worth noting that in these insects, the female can renew its stock of sperms by mating between two egg-laying periods and lay a much greater number of eggs in its lifespan (153 and 203 on average for E. orientalis and D. basalis). Thus, compared to insects, the number of eggs laid seems particularly low in $V$. destructor (Dermanyssoidea: Varroidae) (in theory, on average 12 per female) But, it is much closer to the number of eggs laid by closely related mesostigmatic female mites which have hematophagous habits (but devoid of spermathecae): 23 and 29.5 on average in $D$. gallinae (Dermanyssoidea: Dermanyssidae) (Oliver 1966) and Ornithonyssus sylviarum (Dermanyssoidea: Macronyssidae) (McCulloch and Owen 2012), respectively.

\subsection{The influence of the colony's phenology on the number of spz}

The choice of the four periods in the year is based on particular phenological phases and the different physiological states of the colony: in October (preparatory period for wintering), in December (wintering phase), in March (end of wintering), and in July (beekeeping season). During these four periods, the mean spz stock in phoretic females is very stable.

During the parasite's reproduction phase, the sealed cell always ensures a stable and optimal microcosm for mites' development and the completion of its cycle (Piletskaya 1988).

However, the $V$. destructor female in the phoretic phase is found in different thermal 
environments (Stabentheiner et al. 2003) as well as nutritiously dissimilar ones, in the same way as adult bees on which they transit. We know that in winter, the temperature of bees from clusters, taken individually, varies between 8 and $37^{\circ} \mathrm{C}$ (Stabentheiner et al. 2003). Yet, these variations in temperatures do not seem to influence the spz count of the spermatheca of its parasite.

\subsection{The spermathecal count of female $V$. destructor in phoretic phases}

An absence of a significant difference between the spermathecal content of females in the phoretic phase and that of foundress females having commenced the reproductive phase tends to indicate that all females do participate in the reproductive phase. There does not seem to be any evidence of the existence of a subpopulation with low spermathecal count, maintaining itself in a phoretic phase. Although the mites have filled spermathecae, some of them can be temporarily infertile (Garrido and Rosenkranz 2004). Moreover, we observe that immature spz is present in $7.2 \%$ of phoretic females' spermathecae. In fact, this figure underestimates the proportion of daughter-females because part of these females has already acquired typically morphologically mature spz before the phoretic phase.

\subsection{Spz maturation}

A spz morphology of the mature type seems to be acquired before the end of a 5- to 14-day phoretic period, required to allow the maturation of the reproductive organ (Akimov et al. 1988). However, the phoretic period is not compulsory for the young nulliparous females (Beetsma et al. 1999). Indeed, spz of the mature type is observed in fertilized daughter-females long before the bee hatches, that is, at an age of less than 5 days. It is, thus, quite improbable that the time necessary for spz maturation be the factor delaying $V$. destructor young females from entering into the reproductive phase.

\subsection{The fertilization of oocytes}

Between a sample of foundress females having completed at least one egg-laying cycle and a sample of their fertilized nulliparous daughters, the spermathecal contents yield a significant difference of $9.9 \mathrm{spz}$ per female. The significantly greater number found in nulliparous females, as compared to foundation females, was expected, since we do know that fertilization occurs exclusively before the emergence of the adult bee. The spz stock acquired at that time then decreases over laying periods (since it is not renewed) to fertilize five oocytes per reproductive cycle, representing the female offspring in the drones' brood. This suggests, as was observed in different insects (for example, in social hymenopterous insects (Cournault and Aron 2008) or in crickets (Bretman et al. 2009)), that a positive correlation between the number of spz in the spermatheca and the size of the offsprings produced also exists in the $V$. destructor.

According to Fries and Rosenkranz (1996) and to Martin and Kemp (1997), the mean number of reproduction cycles occurring in females seems to be 2. Theoretically, on the basis of 2 cycles as an average number, a female produces ten oocytes in the drone brood (Martin 1995), which necessitate fertilization. Thus, in real terms, the mean number of spz for the purpose of fertilizing an oocyte is $9.9 / 10=0.99$. In certain insects, the number of spz needed is greater: 1.4 for Drosophila bifurcata Patterson and Wheeler (Joly et al. 2008), 3 to 100 per egg, according to research undertaken on $A$. mellifera (Baer 2005; Rubinsky 2010). However, it does seem closer to 1 in the case of the Oncopeltus fasciatus bug (Dallas) (Gordon and Gordon 1971) and in the parasitoid hymenopterous insect $D$. basalis (Damiens et al. 2002). Such a high fertilization rate presupposes that spz viability is either close to $100 \%$, which is the case for $V$. destructor, as our study indicates (over $91 \%$ ). In $V$. destructor, the mean initial stock of $44.3 \mathrm{spz}$ is therefore sufficient to generate the maximum egg-laying number of 30 fertilized oocytes per female, and 
spz weakening is unlikely to occur if mating takes place without any hindrance. This explains the apparent equivalence between the number of stored spz and the female egg-laying status. Kirrane et al. (2011), however, have shown that the hygienic behavior of certain bee strains, which regularly uncap cells, can generate an increased number of females with spermathecae not fully filled (count below, or equal to $20 \mathrm{spz}$ ). These authors attribute this to the fact that, as was shown by Donzé et al. (1996), several mating phases are necessary inside the cell to reach complete spermatheca filling, so that uncapping can intervene before the number of required mating phases have taken place.

The weakening of spz stock in other arrhenotokous arthropods (of which the unfertilized eggs yield males) does not reduce egglaying size but modifies the sex ratio in favor of males. It is, for instance, the case for the parasitoid insect $D$. basalis and the parasitic poultry mite $O$. sylviarum (Canestrini and Fanzago) (Hamilton 1967; Bressac et al. 2008; McCulloch and Owen 2012). With regard to $V$. destructor, however, the sex ratio cannot evolve in a significant way, since only one unfertilized oocyte per foundation female is laid in the case of mono- or multi-infestation (Fuchs and Langenbach 1989; Martin et al. 1997).

\subsection{Infertility}

The proportion of non-fertilized adult daughter-females in the brood is $21.9 \%$ in the case of our study and $10 \%$ for Martin et al. (1997). This percentage figure is substantially reduced in phoretic females $(6.7 \%$ in our study), and most foundress females which have not produced any offspring do not present an empty spermatheca. A large proportion of nonfertilized daughters do therefore seem to disappear without entering the brood.

In cases of foundress females with no offspring, the cause of infertility, despite the presence of spz in the spermatheca, may be (i) inadequate $\mathrm{spz}$ maturation related, or not, to bees' resistance to mites (Harris and Harbo
1999), (ii) an adaptive alteration in the kairomone activating the reproduction signal, which is emitted by the bee larvae just after capping (Garrido and Rosenkranz 2004; Locke et al. 2012; Frey et al. 2013).

\subsection{Reproductive strategy}

Generally, it appears that the reproductive strategy of $V$. destructor is rather economic and relies on a high level of efficiency with regard to fertilization: the reduced number of eggs per female, the number of spermatozoa close to the minimum necessary for this production, and economy in the number of males. The low rate of eggs per female is not exceptional in mites of the Dermanyssoidea superfamily (see above). It is also the case with very distantly related mites, such as scabies agents (Acari: Sarcoptiforma; 17 to 18 eggs per female according to Timoney (1924)). In hard ticks, however (Acari: Ixodida), several thousand of eggs per female are rather frequent (Vial 2009). This latter strategy can partly be explained by the fact that the eggs are laid at a distance from the host, and that the encounter between the young and the host is subject to great hazards. Such an effort in terms of production therefore allows an increase in the chances that a small number of individuals from the latest batch of eggs will have to reproduce themselves. $V$. destructor, being unable to survive away from the host, makes it impossible for this problem to be an issue. Few eggs are necessary, and the reduced number of spermatozoa stored also probably reflects an economy in the production of male gametes. This strategy, however, leads to an increased sensitivity to a default in insemination, such as is shown by the resistance efficiency of bee strains with hygienic behaviors as described by Kirrane et al. (2011). Moreover, oedipal coupling, which enables a virgin female $O$. sylviarum (McCulloch and Owen 2012) to produce an offspring, does not occur with $V$. destructor. Lastly, the economy in the number of males is likely to restrict genetic diversity (Solignac et al. 2005) and reinforces the lack of sperm competition in parasitic mites (Parker 1970). 
An economy in gametes appears in comparison to rather distant organisms (insects) and does not seem flexible. Indeed, during the period where, under our weather conditions, the reproduction of the parasite is impossible due to the absence of the brood, no restriction in the number of stored spermatozoa was observed. The reduced number of eggs per female may thus be a typical characteristic of specific phylogenetic groups. In addition, the absence of regulation during winter enables the mite to initiate efficient reproduction cycles as soon as the brood returns. This advantage that the mite has on the wintering colony is a rather doubleedged sword. If the colony is weakly infested, for instance, less than 1 year after the primoinfestation, the mite reproduction affects only a small part of the new capped brood. On the opposite side, if the colony is strongly infested, most of the new capped brood is affected, that leads to a rapid decline of the colony due to a drastic reduction of the emergence of healthy adult bees.

The absence of fertilization or mating seems to lead to a rather rapid death (eradication of females with empty spermathecae between the period of life in the cell and the phoresic period), whereas different charged spermathecae do not seem to influence parasitism behavior. In D. gallinae, pseudogamy is necessary for egglaying: without the mating act, unfertilized eggs are not matured; the mating act leads to their maturation without necessarily fertilizing them (Hutcheson and Oliver 1988). Perhaps, the mating act is necessary for the process of the parasitism cycle in $V$. destructor.

The optimization of fertilization by spermatozoa appears close to perfection, and spermatozoon maturity is acquired sufficiently fast so that it is not a limiting factor in the dynamics of mite populations. Consequently, the main modulating factor for reproductive success likely to affect the population dynamics of $V$. destructor, apart from changes directly linked to the host colony seems to be the presence, and activity of the male whose task is to ensure that the spermathecae of several daughter-females is filled. The death of the unique male in mono- infested cells (Martin and Kryger 2002) and the opening of parasitized cells (Vandame et al. 2002; Locke et al. 2012) are key events in limiting proliferation.

Lastly, observing cases of female infertility despite the presence of spermatozoa in spermathecae supports the hypothesis in favor of the individual resistance of hosts, for instance through the reduced emission of kairomonal signals inducing oogenesis or by means of physiological mechanisms of host resistance yet to be explored.

\section{ACKNOWLEDGMENTS}

The study was carried out under the FEAGA 1254R (European Agricultural Guarantee Fund, or EAGF) European project.

Fécondation et fertilité de la femelle Varroa destructor: un point-clé de la dynamique parasitaire

Apis mellifera / spermathèque / succès reproducteur / relation hôte parasite

Die Befruchtung und die Fertilität bei Varroa destructor Weibchen sind Schlüsselfaktoren für die Populationsdynamik des Parasiten

Varroa destructor / Apis mellifera / Parasit / Spermatheka / Reproduktionserfolg

\section{REFERENCES}

Akimov, I.A., Yastrebstov, A.V. (1984) Reproductive system of Varroa jacobsoni. I. Female reproductive system and oogenesis. Vestn. Zool., 6, 61-68 [in Russian].

Akimov, I.A., Piletskaya, I.V., Yastrebtsov, A.V. (1988) Modifications morpho-fonctionnelles dues à l'âge dans le système reproducteur des femelles de Varroa jacobsoni. Vestn. Zool., 6, 48-55 [in Russian].

Al-Lawati, H., Kamp, G., Bienefeld, K. (2009) Characteristics of the spermathecal contents of old and young honeybee queens. J. Insect Physiol., 55, 117122.

Anderson, D.L., Trueman, J.W. (2000) Varroa jacobsoni (Acari: Varroidae) is more than one species. Exp. Appl. Acarol., 24, 165-189. 
Baer, B. (2005) Sexual selection in Apis bees. Apidologie, 36, 187-200.

Beetsma, J., Boot, W.J., Calis, J. (1999) Invasion behaviour of Varroa jacobsoni Oud.: from bees into brood cells. Apidologie, 30, 125-140.

Björndahl, L., Soderlund, I., Kvist, U. (2003) Evaluation of the one-step eosin-nigrosin staining technique for human sperm vitality assessment. Human Reprod., 18 (4), 813-816.

Bressac, C., Damiens, D., Chevrier, C. (2008) Sperm stock and mating of males in a parasitoid wasp. J. Exp. Zool. (Mol. Dev. Evol.), 310B, 160-166.

Bretman, A., Newcomb, D., Tregenza, T. (2009) Promiscuous females avoid inbreeding by controlling sperm storage. Mol. Ecol., 18, 3340-3345.

Cournault, L., Aron, S. (2008) Rapid determination of sperm number in ant queens by flow cytometry. Insectes Soc., 55, 283-287.

Damiens, D., Bressac, C., Brillard, J.P., Chevrier, C. (2002) Qualitative aspects of sperm stock in males and females from Eupelmus orientalis and Dinarmus basalis (Hymenoptera: Chalcidoidea) as revealed by dual fluorescence. Physiol. Entomol., 27, 97-102.

Donzé, G., Guérin, P.M. (1994) Behavioral attributes and parental care of Varroa mites parasitizing honeybee brood. Behav. Ecol. Sociobiol., 34, 305-319.

Donzé, G., Herrmann, M., Bachofen, B., Guérin, P.M. (1996) Effect of mating frequency and brood cell infestation rate on the reproductive success of the honeybee parasite Varroa jacobsoni. Ecol. Entomol., 21, 17-26.

Frey, E., Odemer, R., Blum, T., Rosenkranz, P. (2013) Activation and interruption of the reproduction of Varroa destructor is triggered by host signals (Apis mellifera). J. Invertebr. Pathol., 113, 56-62.

Fries, I., Rosenkranz, P. (1996) Number of reproductive cycles of Varroa jacobsoni in honey-bee (Apis mellifera) colonies. Exp. Appl. Acarol., 20, 103-112.

Fuchs, S. (1994) Non-reproducing Varroa jacobsoni Oudemans in honey bee worker cells - status of mites or effect of brood cells? Exp. Appl. Acarol., 18, 309-317.

Fuchs, S., Langenbach, K. (1989) Density-dependent reproduction of Varroa jacobsoni and impact on population growth. In: Present status of varroatosis in Europe and progress in the Varroa mite control. Ed. R Cavalloro, CEE Official Publications, Luxembourg.

Garrido, C., Rosenkranz, P. (2004). Volatiles of the honey bee larva initiate oogenesis in the parasitic mite Varroa destructor. Chemoecologie, 14, 193196.

Gordon, B.R., Gordon, H.T. (1971) Sperm storage and depletion in the spermatheca of Oncopeltus fasciatus. Entomol. Exp. Appl. Acarol., 14, 425-433.

Hamilton, W.D. (1967) Extraordinary sex ratios. Science, 156, 477-488.
Harris, J.W., Harbo, J.R. (1999). Low sperm counts and reduced fecundity of mites in colonies of honey bees (Hymenoptera: Apidae) resistant to Varroa jacobsoni (Mesostigmata: Varroidae). J. Econ. Entomol., 92, 83-90.

Hutcheson, H.J., Oliver, J.H. Jr. (1988) Spermiogenesis and reproductive biology of Dermanyssus gallinae (Parasitiformes: Dermanyssidae). J. Med. Entomol., 25, 321-330.

Joly, D., Luck, N., Dejonghe, B. (2008) Diversité morphologique et fonctionnelle des spermatozoïdes chez les drosophiles. J. Soc. Biol., 202, 103-112.

Kirrane, M.J., De Guzman, L.I., Rinderer, T.E., Frake, A.M., Wagnitz, J.J., Whelan, P.M. (2011) Asynchronous development of honey bee host and Varroa destructor (Mesostigmata: Varroidae) influences reproductive potential of mites. J. Econ. Entomol., 104, 1146-1152.

Kiszewsky, A.E., Spielman, A. (2002) Preprandial inhibition of re-mating in Ixodes ticks (Acari:Ixodidae). J. Med. Entomol., 39, 847-853.

Locke, B., Le Conte, Y., Crauser, D., Fries, I. (2012) Host adaptations reduce the reproductive success of Varroa destructor in two distinct European honey bee populations. Ecol. Evol., 2(6), 1144-1150.

Martin, S.J. (1994) Ontogenesis of the mite Varroa jacobsoni Oud. in worker brood of the honeybee Apis mellifera L. under natural conditions. Exp. Appl. Acarol., 18, 87-100.

Martin, S.J. (1995) Ontogenesis of the mite Varroa jacobsoni Oud. in drone brood of the honeybee Apis mellifera L. under natural conditions. Exp. Appl. Acarol., 19, 199-210.

Martin, S.J., Kemp, D. (1997) Average number of reproductive cycles performed by the parasitic mite Varroa jacobsoni in Apis mellifera colonies. J. Apic. Res., 36, 113-123.

Martin, S.J., Kryger, P. (2002). Reproduction of Varroa destructor in South African honey bees: does cell space influence Varroa male survivorship? Apidologie, 33, 51-61.

Martin, S.J., Holland, K., Murray, M. (1997) Nonreproduction in the honeybee mite Varroa jacobsoni. Exp. Appl. Acarol., 21, 539-549.

McCulloch, J.B., Owen, J.P. (2012) Arrhenotoky and oedipal mating in the northern fowl mite (Ornithonyssus sylviarum) (Acari: Gamasida: Macronyssidae). Parasit. Vectors, 5, 281.

Oliver, J.H. Jr. (1966) Notes on reproductive behavior in the Dermanyssidae. J. Med. Entomol., 3, 29-35.

Oliver, J.H. Jr. (1977) Cytogenetics of mites and ticks. Annu. Rev. Entomol., 22, 407-29.

Parker, G.A. (1970) Sperm competition and its evolutionary consequences in the insects. Biological Reviews, 45, 525-567.

Piletskaya, I. (1988) Particularités du développement de Varroa jacobsoni dans le couvain d'ouvrières et de faux-bourdons. Vestn. Zool., 2; 40-43 [in Russian]. 
Rosenkranz, P., Frey, E., Odemer, R., Mougel, F., Solignac, M., Locke, B. (2009) Variance of the reproduction of the parasitic mite Varroa destructor and its significance for host resistance at the individual level. In: Abstract 41, Apimondia congress, 15-20 septembre 2009, Montpellier.

Rosenkranz, P., Aumeier, P., Ziegelman, B. (2010) Biology and control of Varroa destructor. J. Invertebr. Pathol., 103, 596-S119.

Rubinsky, M. (2010) Sperm use during egg fertilization in the honeybee (Apis mellifera). ISP Collection, Paper 914, 26 pp.

Solignac, M., Cornuet, J.M., Vautrin, D., Le Conte, Y., Anderson D. et al. (2005) The invasive Corea and Japan types of Varroa destructor, ectoparasitic mites of the Western honeybee (Apis mellifera), are two partly isolated clones. Proc. R. Soc. B, 272, 411419.

Stabentheiner, A., Press, H., Papst, T., Hrassnigg, N., Crailsheim, K. (2003) Endothermic heat production in honeybee winter clusters. J. Exp. Biol, 206, 353358.

Timoney, T.M. (1924) The bionomics of the sarcoptic mange parasite of the buffalo, with some observations concerning the relative power of resistance to adverse conditions of the different stages of the Acarus and of its egg. Bull. Imp. Inst. Agric. Res., Pusa, 154, 180-200.

Vandame, R., Morand, S., Colin, M.E., Belzunces, L. 2002 Parasitism in the social bee Apis mellifera: quantifying costs and benefits of behavioural resistance to Varroa destructor mites. Apidologie, 33, 433-445.

Vial, L. (2009) Biological and ecological characteristics of soft ticks (Ixodida: Argasidae) and their impact for predicting tick and associated disease distribution. Parasite, 16, 191-202.

Winston, M.L. (1993) La biologie de l'abeille. Translated from English by G. LAMBERMONT. Edition Frison Roche, Paris. 